\title{
Infokommunikációs technológia használata kora gyermekkorban
}

\author{
Faragó BoglárKa - Kecsieméti-SzÉKely Katalin Zsuzsa - \\ DÁvid MÁRIA \\ Eszterházy Károly Egyetem
}

\begin{abstract}
A jelen tanulmányban áttekintjük az információs és kommunikációs technológiák (TV, internet) koragyermekkori használatára vonatkozó hazai és nemzetközi kutatási eredményeket, és bemutatjuk az Eszterházy Károly Egyetemen e témában folytatott empirikus vizsgálat eredményeit. Kutatásunk célja annak feltárása volt, hogy milyen IKT-használati szokások jellemzik a hat év alatti gyermekeket a szülők megkérdezése alapján. Bemutatásra kerül az általunk kidolgozott IKT-használati kérdöív, valamint a kérdőives vizsgálat föbb eredményei. Vizsgálati eredményeink azt mutatják, hogy a hat év alatti gyermekek IKT-használata nem minden esetben a nemzetközi ajánlásnak megfelelöen alakul. A szakemberek számára ezért a legfontosabb feladat a szülök célzott támogatása abban, hogy hogyan tudnak segiteni gyermeküknek egészen koragyermekkortól a késóbbi megfelelö, adaptiv IKT-használat megalapozásában.
\end{abstract}

Kulcsszavak: kora gyermekkor, IKT-használat, multitasking, szülői kontroll

\section{Bevezetés}

Sok kutatás foglalkozik az infokommunikációs technológiai (IKT) eszközök különböző kognitív képességekre, érzelmekre, tanulásra gyakorolt hatásával. Ezek a kutatások főként az idősebb gyermekek, serdülők vagy felnőttek IKT-használatának következményeire irányulnak, ugyanakkor keveset tudunk arról, hogy milyen hatást gyakorol ezeknek az eszközöknek a gyakori használata a legfiatalabbakra - a csecsemő- és kisgyermekkorú, valamint óvodáskorú gyermekekre.

Saját korábbi vizsgálatunkban a 10-18 éves korosztály IKT-használati szokásait felmérve azt tapasztaltuk, hogy három korcsoportra bontva a mintában szereplő vizsgálati személyeket (18 éves, 14 éves és 10 éves korosztály), egyre korábbi életkorra tolódik az az időpont, amikor a gyermek elkezdi használni a különböző IKT-eszközöket. (A 18 évesek átlagosan 9,5 év, a 14 évesek átlagosan 8 év, míg a 10 évesek átlagosan 6,5 év.) (Dorner et al., 2016).

Korábban azt gondolták, hogy a hároméves kor előtti tapasztalatoknak csak korlátozott szerepük van a későbbi fejlődés szempontjából, ma már azonban tudjuk, hogy a korai tapasztalatok rendkívül nagy hatást gyakorolnak az agyi architektúrára, valamint a képességek alakulására. Mára azt is tudjuk, hogy egy három év alatti gyermek agya kétszer olyan aktív, mint egy föiskolásé (Shore, 1997). A technológiai eszközök ma már mindennapi környezetünk részét képezik, így a gyermekek találkoznak ezekkel az eszközökkel ebben a rendkívül szenzitív időszakban. Fő kérdésünk az, hogy milyen hatásai lehetnek ennek a találkozásnak.

\section{Elméleti áttekintés}

Koragyermekkorban az agy plaszticitása, változásra való képessége igen nagy. „...a fejlődésben lévő idegrendszert nagyobb eséllyel befolyásolják különféle környezeti tényezők, mint a kifejlett agyat, s ezek a hatások megnövekedett vulnerabilitás kialakulásához vezethetnek" (Feldmann és Nagy, 2016, o.n.). Egyes szerzők szerint lehetséges, hogy a gyakori technológiahasználat ebben az életkorban kifejezettebb hatást gyakorol, mint felnőttkorban éppen a nagyobb idegi plaszticitás következtében (Wilmer, Sherman E Chein, 2017). Egy 76 kutatás eredményeit áttekintő 
összefoglaló tanulmányban, melyben a koragyermekkori tévénézés és kognitív müködés közötti összefüggéseket tárták fel, a szerzők megállapítják, hogy a három év előtti időszak egy igen szenzitív szakasz az agy fejlődésében, és az agy érése olyan központi kognitív képességek fejlődésével jár együtt, mint például a figyelem vagy a munkamemória. A szerzők szerint a jelenleg rendelkezésre álló kutatások eredményeiből nem állapítható meg egyértelműen, hogy a csecsemőkori gyakori tévénézés hosszútávú hatással van-e a fejlődő agyra, mert a legtöbb ezzel kapcsolatos kutatás korrelációs jellegű, így oksági kapcsolat megállapítására nem alkalmas. Ehelyett hosszútávú longitudinális vizsgálatokra lenne szükség (KostyrkaAllchorne, Cooper E Simpson, 2017a).

Egy ilyen longitudinális vizsgálatban azt találták, hogy a figyelemmel, emlékezettel, végrehajtó funkciókkal és nyelvi feldolgozással összefüggő agyi területeken alacsonyabb mértékű szürke- és fehérállomány növekedés volt megfigyelhető három év elteltével azoknál a gyerekeknél, akik gyakrabban használták az internetet. Ebben a vizsgálatban a résztvevő gyermekek átlagéletkora a hároméves vizsgálati periódus végén 14,2 év volt, tehát ez a vizsgálat sem koragyermekkori médiahasználat hatására irányult (Takeuchi et al., 2018).

$\mathrm{Az}$ internetfüggőség, vagy problémás internethasználat is megjelenik a modern technológia világában. Az internetfüggőség a viselkedéses addikciók közé tartozik. Fontos elkülöníteni az internetaddikciót a problémás internethasználattól, hiszen „előbbi klinikai figyelmet igényel, míg utóbbi, bár számos problémát okozhat a mindennapi életben inkább tüneti viselkedésnek tekinthetö" (Demetrovics, 2013. 156. o.).

Az internetfüggőséget különböző módokon konceptualizálják a szakirodalomban. A Demetrovics Zsolt által kialakított Problémás Internethasználat Kérdőív (PIUQ) a következő faktorokat foglalja magába: az első faktor az obszesszió, ami azt jelenti, hogy a személy gondolataiban mennyire jelenik meg az internettel való foglalkozás (pl. ábrándozás), valamint, hogy mennyire jelenik meg feszültség az internet hiányában. A második faktor az elhanyagolás, amely azt jelenti, hogy a személy elhanyagolja-e mindennapi tevékenységeit, szükségleteit az internethasználat következtében. Végül az utolsó faktor a kontrollzavar, vagyis, hogy a személy mennyire képes kontrollálni az internethasználatát. A kérdőívvel végzett vizsgálatot 9 és 69 év közötti személyekkel végezték (összesen 1037 fóvel), és azt találták, hogy minden faktoron a 18 évnél fiatalabbak érték el a legmagasabb értéket (Demetrovics, 2013). A serdülők és a fiatal felnőtt egyetemisták veszélyeztetettebbek a problémás internethasználat kialakulására (életkori és életmódbeli sajátosságaik miatt) (Demetrovics, 2013).

Kérdés, hogy a fejlődésben lévő idegrendszer fogékonyabb-e a függőség kialakulására? Amit tudunk, hogy „a prefrontális kortex látja el a döntéshozatali funkciót, mivel a tapasztalatok ismétlődő vonásaiból szabályokat alkot, mely alapján kiválasztja a megfelelő viselkedési reakciókat. Kontrollfunkciója révén felülírhatja a reflexfolyamatokat. A függőség fenntartásában, illetve a visszaesés kockázatát illetően is fontos a prefrontális kortex szerepe" (Fekete és Vörös, 2016. o.n.). A prefrontális lebeny fejlődése elnyújtott, vagyis érése kitolódik egészen a serdülőkor közepéig, szemben a motoros és szenzoros területek, illetve a temporális és parietális asszociációs kérgi területek érésével (Casey, Tottenham, Liston \& Durston, 2005). Így a koragyermekkori éretlen prefrontális lebeny nagyobb vulnerabilitással járhat a különböző függőségek kialakulására. Saját vizsgálatunkban mi is törekedtünk azoknak az érzelmi jelzéseknek a feltárására, amelyek a problémás internet-, illetve IKT-használatra mutatnak (erről részletesebben a Vizsgálati eszköz c. fejezetben lesz szó).

Egy 2017-es vizsgálatban a három- és hat év közötti gyermekek média preferenciáját és használatát, a szülők médiahasználatát, a koragyermekkorban megjelenő multitasking, többszörös feladatvégzés jelenségét mérték fel, valamint a szülői ellenőrzés mértékét, és a szülői hiedelmeket a gyermek médiahasználatával kapcsolatban. Vizsgálati személye- 
ik a 3-6 éves gyerekek szülei voltak (összesen 90 fö). A kérdőíves vizsgálat eredményei szerint ebben az életkorban a legkedveltebb médiaeszköz a televízió, melyet a gyermekek átlag heti nyolc órában néznek, a gyerekek teljes heti médiafogyasztása átlag 13,42 óra, a gyerekek heti médiahasználatának negyven százaléka érintőképernyős eszközön valósul meg (tableten vagy okostelefonon). A szerzők pozitív kapcsolatot találtak a média multitasking és a tablet/okostelefon használata között, vagyis úgy tűnik, ezen érintőképernyős eszközök elérhetősége facilitálja a multitaskingot. Ennek oka a szerzők szerint az eszköz könnyű kezelhetősége, mely az ilyen kicsi gyerekek számára is lehetővé teszi, hogy egyszerüen navigáljanak a különböző oldalak között. Ennek a szülői kontroll szempontjából is van jelentősége, hiszen a szülő számára egyébként is kihívást jelenthet a hordozható eszközökön végzett tevékenység ellenőrzése, különösen akkor, ha még több tartalmat is fogyaszt rajta a gyerek szimultán. Emellett több média szimultán fogyasztása rendkívül megnehezíti annak megítélését is a szülő számára, hogy gyermeke összesen mennyi időt tölt el technológiai eszköz használatával. A multitasking, valamint általában a gyorsan változó digitális tartalom kihívások elé állítja a gyermekek éretlen idegrendszerét is, ezzel befolyásolva a gyermekek kognitív funkcióinak (pl. figyelmének, emlékezetének) fejlődését (Kostyrka-Allchorne, Cooper E Simpson, 2017b).

Csecsemő- és kisgyermekkorban a tapasztalatok elsajátításában, a tanulásban döntő szerepe van a szemtől szembeni interakcióknak és a cselekvés útján történő tapasztalatszerzésnek. Ezek a tevékenységek háttérbe szorulhatnak a gyermek, vagy akár a szülő médiahasználata következtében is. A mobil eszközök gyakori szülői használata következtében csökken a verbális és nonverbális szülőgyermek interakció, a szülő tévézése a gyermek játéka közben mezavarhatja a gyermeket játéktevékenységében. Emellett a szülők modellszerepe is jelentős; a szülő médiahasználata prediktora a gyermekének (AAP Council on Communications and Media, 2016).
A kutatások szerint a koragyermekkori tévénézés negatív hatásainak hátterében több tényező is áll. Egyrészt a tévénézés csökkenti a szülő-gyermek interakciók számát. Másrészt direkt módon helyettesíti azokat a tevékenységeket, amelyek életkori szempontból a legmegfelelőbbek lennének a gyermek fejlődéséhez (pl. játék, mozgás, manipuláció). Harmadrészt ebben az életkorban a gyermekek még nem képesek arra, hogy tanuljanak a televízióban látottakból (Kostyrka-Allchorne et al., 2017a). Szimbolikus gondolkodási és figyelmi képességeik fejletlenek, amely megnehezíti számukra, hogy a médiából szerzett tapasztalatokat a valódi világban alkalmazzák (AAP Council on Communications and Media, 2016).

Az Amerikai Gyermekgyógyászati Akadémia (AAP) csecsemő- és kisgyermekkorú, valamint óvodáskorú gyermekek médiahasználatára vonatkozó ajánlásában megfogalmazza, hogy limitált kutatási eredményekkel rendelkezünk arra vonatkozóan, hogy a kétéves kor alatti digitális média használat pozitív hatást gyakorolhat a gyermekek fejlődésére. Egyedüli kivételként a különböző videóchatet alkalmazásokat említik, viszont annak használatában is elengedhetetlennek tartják a szülöi ellenőrzést, kontrollt. A videóchat alkalmazásával kapcsolatos kivétel feltehetően annak szól, hogy Amerikában a családtagok időnként több száz kilométerre laknak egymástól, (pl. nagyszülők, és a gyermeket nevelő család) és így a „csetelés” a családi interakciók részévé, a szociális kapcsolattartás eszközévé vált.

Az Amerikai Gyermekgyógyászati Akadémia a következő ajánlásokat fogalmazza meg a szülők számára a koragyermekkori médiahasználatra vonatkozóan:

- Lehetőség szerint 18-24 hónaposnál fiatalabb gyerekek ne használjanak digitális média eszközt (a videóchat kivételével).

- Sokszor a szülő nyomásként éli meg, hogy minél korábbi életkorban megismertesse gyermekét a technológiai eszközök használatával attól való félelmében, hogy ellenkező esetben gyermeke lemarad a többiekhez képest. A társaság szerint ugyanakkor ettől nem 
kell tartani, a gyermekek a későbbiekben nagyon gyorsan be tudják hozni az ezzel kapcsolatos esetleges lemaradásukat.

- Két- és ötéves kor között korlátozni kell a médiahasználat időtartamát; ez ne legyen több, mint napi egy óra.

- Ebben az egy órában a szülö folyamatosan legyen a gyermek mellett, segítsen számára értelmezni a látottakat, hallottakat, vegyen részt a gyermek médiahasználatában.

- A megtekintett tartalmat a gyermek életkorához kell igazítani. Vagyis a szülőnek nemcsak az időtartam, de a tartalom szempontjából is fontos kontrolláló szerepe van. Az erőszakos és dinamikusan változó tartalmakat kerülni kell (utóbbinak a feldolgozására a gyermek éretlen idegrendszere nem feltétlenül képes még). Minden programot, digitális alkalmazást próbáljon ki, nézzen meg a szülő, mielőtt gyermeke megtekintené/használná azt.

- Ne a digitális médiaeszköz legyen a gyermek megnyugtatásának egyetlen eszköze. Ha ilyen módon használja a gyermek a médiát, az megnehezíti számára a saját érzelemszabályozási stratégiák kialakítását.

- Legyenek a család otthonában olyan helyiségek, ahol nem lehet médiaeszközt használni. Ebből a szempontból különösen fontos, hogy a hálószoba technológiamentes tér legyen, hiszen az ilyen eszközök gyakran megzavarják a nyugodt alvást. Emellett az is fontos, hogy egy órával lefekvés előtt már ne használja a gyermek a technológiai eszközt.

- Legyenek olyan közös tevékenységek, mely során nem engedélyezett a digitális média használata, nemcsak a gyermek, de a szülő számára sem. Ezek főként azok a közös tevékenységek, melyek a gyermek fejlődésében, a pozitív szülőgyermek interakcióban jelentősek (pl. közös játék, étkezés, meseolvasás) (AAP Council on Communications and Media, 2016).

Kérdés, hogy ehhez az ajánláshoz képest milyen a valóság. A fentebb már említett, több kutatás eredményét összegző tanulmányban a szerzők azt állapítják meg, hogy a szülői kontroll nem mindig valósul meg a gyermek médiahasználata fölött, gyakran „di- gitális bébiszitter" funkciója van a tévének. Önmagában az nem elég, ha a szülő fizikailag egy térben, egy szobában van a gyerekkel, míg a gyermek tévét néz. Az még nem jár együtt automatikusan a gyermek médiafogyasztásának segítésével, és kontrolljával, ha egy légtérben van a szülőkkel (Kostyrka-Allchorne et al., 2017a).

A másik kutatásban, melyben a 3-6 éves gyerekek technológiahasználatát vizsgálták, azt találták, hogy a szülők ritkán járnak személyesen utána annak, hogy a gyermekek számára ajánlott tartalmak valóban megfelelőek-e a számukra, inkább meglévő értékelésekre támaszkodnak ebben. Emellett, bár a szülők azzal általában tisztában vannak, hogy az erőszakos, valamint nem megfelelő nyelvezetet használó és viselkedést bemutató tartalmakat kerülni kell ebben az életkorban, azt már kevesebben tudják, hogy a túlságosan gyors tempóban változó digitális tartalom mennyire megterheli gyermekük figyelmét. (Kostyrka-Allchorne et al., 2017b).

Magyarországon 2017 októbere és 2018 februárja között végeztek egy nagymintás felmérést annak feltárása érdekében, hogy milyen televízió- és internethasználati szokások jellemzik a három év alatti gyermekeket. A kutatásban a szülőket kérdezték meg gyermekeik médiafogyasztásával kapcsolatban online kérdőív formájában, összesen 1087 szülő vett részt a vizsgálatban. A szerzők rákérdeztek, hogy a szülő szerint mennyi az az ideális időtartam, amelyet egy ilyen életkorú gyermek tévénézéssel tölthet. Erre a kérdésre a leggyakoribb válasz $(37,4 \%)$ a fél-egy óra volt. Hétvégén többet néznek tévét a gyermekek, mint hétköznap, a tévé helye a lakások 79\%-ában a nappaliban található, az ezt követő legnagyobb gyakoriságú válasz pedig a hálószoba volt (43,5\%), de a megkérdezettek gyermekeinek szobájában is 11,8\%-ban megtalálható a készülék.

$\mathrm{Az}$ internetezés kevésbé volt jellemző a mintában, mint a televíziónézés, ha mégis megjelent, akkor a legnagyobb gyakorisággal okostelefonon keresztül (38,5\%), ezt követte a tableten történő internethasználat $(24,1 \%)$. Az ebben a vizsgálatban a szülőknek feltett 
kérdések közül néhányat a mi kutatásunkban is alkalmaztunk annak érdekében, hogy adataink összehasonlíthatóvá váljanak a nagymintás mérés eredményeivel. Így mi is rákérdeztünk, hogy milyen céllal biztosítja a szülő a gyermek számára a médiaeszközök elérhetőségét. A szerzők eredménye szerint közel azonos gyakorisággal jelenik meg a válaszok között a gyermek szórakoztatásának igénye, a gyermek fejlesztése, valamint az, hogy a szülőnek van szüksége egy kis időre, amíg a gyermeket lefoglalja valami. Szintén megjelent a mi kutatásunkban is az a kérdés, hogy a szülő szerint van-e valamilyen hasznos funkciója a tévénézésnek. A több mint 1000 főt számláló vizsgálat eredményei szerint a három leggyakrabban említett hasznos funkció; a gyermek ismereteinek bővítése, a gyermek szókincsének fejlesztése, valamint az idegen nyelv tanulásának elősegítése (Nemzeti Média-és Hírközlési Hatóság, 2018).

\section{Kutatás a kisgyermekek infokommunikációs technológia (IKT) használatáról}

Saját vizsgálatunkban egy empirikus feltáró kutatást terveztünk. Azt vizsgáljuk, hogy a fentebb megfogalmazott ajánlásokhoz képest milyen IKT-használat és szülői kontroll jelenik meg a hat év alatti gyermekek esetében. A fentebb bemutatott nagymintás magyar kutatáshoz képest az általunk alkalmazott vizsgálati módszer szélesebb körűen tekinti át a használt IKT-eszközök körét, valamint az IKT-használat jellegzetességeit. Míg a fenti vizsgálat elsősorban a televíziónézésre, gyermekek által nézett tartalmakra, fóként az általuk nézett mesékre irányul, addig saját vizsgálatunkban további elemként jelenik meg a multitasking, a problémás IKT-használatra utaló jelzések vizsgálata, valamint a szülői kontroll kérdése a gyermek IKT-használatával kapcsolatban. A következőkben az ezzel kapcsolatban kidolgozott kérdöív és a kapott eredmények bemutatására fókuszálunk.

A kutatás feltáró jellege miatt, előzetes hipotéziseket nem fogalmaztunk meg a kora- gyermekkori IKT-használatra vonatkozóan. Elsősorban arra voltunk kíváncsiak, hogy az általunk kapott adatok hogyan viszonyulnak a nemzetközi ajánlásokhoz, így a következőkben az eredményeket a fentiekben bemutatott Amerikai Gyermekgyógyászati Akadémia (AAP) által megfogalmazott ajánlások tükrében közöljük.

Vizsgálatunk egy nagyobb kutatás részét képezte, melyben nemcsak a koragyermekkori IKT-használatot, hanem a nyelvfejlődést is felmértük a Kommunikatív Fejlődési Adattár (16-30 hónaposok részére) segítségével, hiszen célunk volt az is, hogy összefüggést keressünk a koragyermekkori nyelvi fejlettség és IKT-használat között. A kétféle kérdőívből származó adatokat kódszámmal tettük összekapcsolhatóvá, a szülőt a kérdőív kitöltésének kezdetén arra kértük, hogy adja meg gyermeke kódját, mely a következőkből tevődött össze: a gyermek születési évének és hónapjának számjegyei, valamint a gyermek keresztnevének első három betüje. Ilyen módon a vizsgálat teljesen anonim volt, a vizsgálatban részt vevő gyermekek nem voltak beazonosíthatók. A vizsgálatban történő részvétel önkéntes volt, azt bármikor meg lehetett szakítani a megkezdését követően.

Az online kérdőív egy rövid bevezető szöveggel indult, melyben informáltuk a szülőt a vizsgálat céljáról és feltételeiről. A bevezetőt követően a szülőt arra kértük, hogy amenynyiben egyetért a feltételekkel, és hozzájárul a kutatásban való részvételhez, akkor azt a következő kérdésre adott „Igen” válasszal igazolja: „A kutatásban való részvételem körülményeiről részletes tájékoztatást kaptam, a feltételekkel egyetértek". A kérdőív további része csak azon személyek számára vált láthatóvá, akik a fenti kérdésre „igen” választ adtak. Vizsgálatunk végrehajtását etikai bizottság hagyta jóvá.

\section{Vizsgálati minta}

Vizsgálati személyeink három év alatti gyermekek szülei voltak, őket kérdeztük gyermekük IKT-használatáról. Összesen 192 fó vett részt a vizsgálatban (182 esetben az anya, 10- 
ben az apa volt a kitöltő személy). A vizsgálatban részt vevő gyermekek átlagéletkora 36,17 hónap, vagyis körülbelül 3 év. A következő két kördiagram a szülők iskolai végzettségét mutatja százalékos eloszlásban.
Az 1. diagramról látható, hogy a legnagyobb gyakorisággal a középiskolai érettségi jelenik meg, az anyák 33,9\%-ának ez a legmagasabb iskolai végzettsége. Ezt követi 29,2\%-kal az egyetemi, majd 25,5\%-kal a föiskolai végzettség.

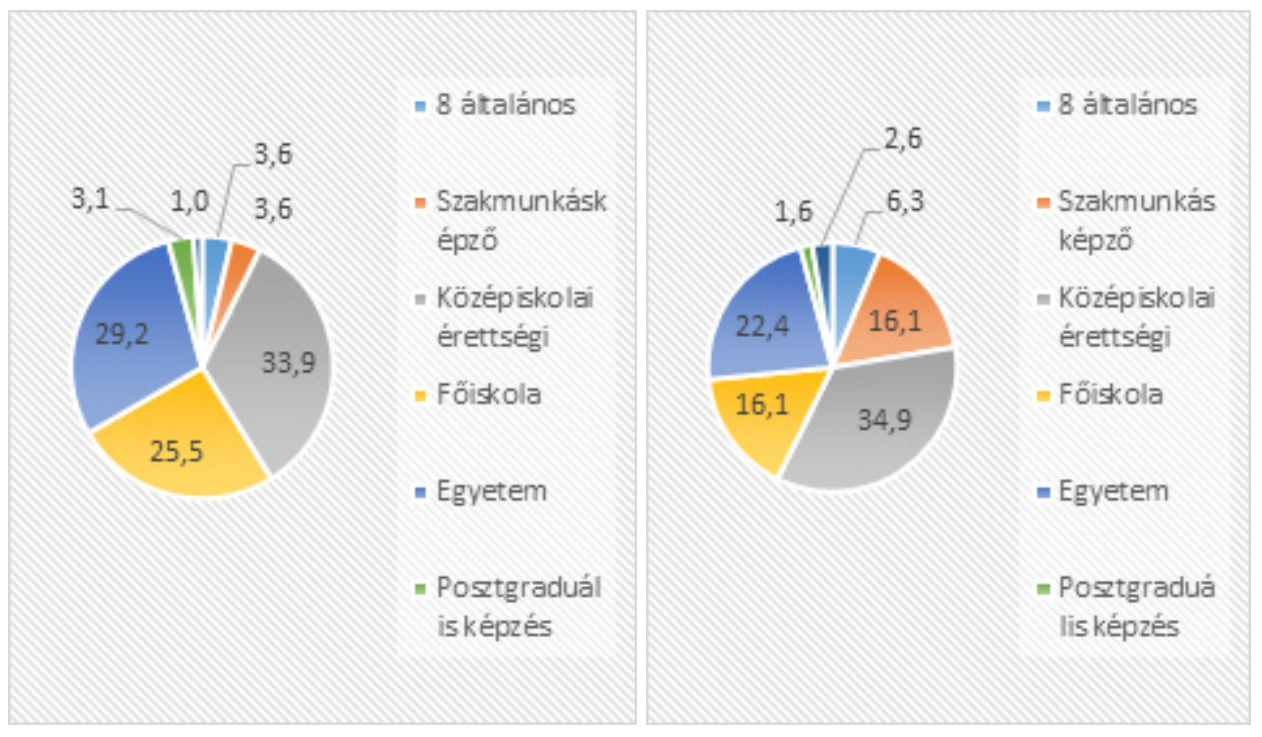

1. diagram: Az anya iskolai végzettsége, 2. diagram: Az apa iskolai végzettsége

A második diagram azt mutatja, hogy a vizsgálatban részt vevő gyermekek édesapjának 34,9\%-ban középiskolai érettségije van, $22,4 \%$ végzett egyetemet, illetve 16,1-16,1\% főiskolát és szakmunkásképzőt.

Vagyis összességében megállapítható, hogy a mintában részt vevő gyermekek szülei az országos átlagnál magasabb iskolai végzettséggel rendelkeznek, melyet az adatok értelmezésekor mindenképp figyelembe kell venni.

A résztvevők 37,5\%-a megyeszékhelyen él, 30,2\%-a városban, 19,3\%-a Budapesten, 13\%-a faluban. Az anya foglalkozása a minta 47,9\%-ában alkalmazott (beosztott), a minta 33,9\%-ában az anya gyermekgondozási ellátást kap. Az apa foglalkozása a minta 58,3\%ában alkalmazott (beosztott), 24,5\%-ban az apa vezető beosztásban dolgozik.

A vizsgálatban részt vevő szülők gyermekeinek 64,6\%-a igénybe vesz vagy vett bölcsödei ellátást, 35,4\% nem.

\section{Vizsgálati módszer}

Kutatási módszerként a kérdőíves kikérdezést választottuk. Online önkitöltős kérdőívet készítettünk, melynek alapja egy koráb- bi vizsgálatunkban a 10-18 éves korosztály IKT-használati kérdőívünk volt (Dorner et al., 2016).

Az online kérdőívet kiegészítettük a bevezetésben már említett 2017-2018-as magyar kutatásban alkalmazott kérdésekkel:

- Milyen célból biztosítja gyermeke számára a tömegkommunikációs eszközök (TV/rádió/DVD/internet) használatát?

- Miközben a gyermeke tv-t/videót/ DVD-t néz, On leggyakrabban mit szokott csinálni?

- Miközben a gyermeke számítógépezik, Ön leggyakrabban mit szokott csinálni?

- A tévénézésnek/IKT eszközhasználatnak/internetezésnek nemcsak hátrányai, hanem előnyei is lehetnek. Kérjük, hogy az alábbiak közül válassza ki azt a hármat, amelyet a TV-nézés/IKT eszközhasználat/internetezés leghasznosabb funkcióinak tart! (Nemzeti Média- és Hírközlési Hatóság, 2018).

Kérdöívünk összesen 54 kérdést tartalmazott, melyek öt kérdéscsoportra bonthatók.

Az első 16 kérdés a demográfiai adatokra vonatkozik (gyermek életkora, szülők iskolai végzettsége, lakóhely stb.). 
Az ezt követő részben az IKT-eszközökkel való ellátottságot mértük fel, vagyis azt, hogy a különböző IKT-eszközök közül mennyi van a családban, illetve, hogy van-e a gyereknek saját mobilja, számítógépe, a bölcsődében, ahová a gyermek jár használnak-e IKTeszközt.

Az IKT-használati szokásokra vonatkozó kérdések segítségével rákérdeztünk arra, hogy mikor használta a gyermek először önállóan az eszközt. Ha egyéves kor alatt jelent meg elöször az adott technológiai eszköz használata, akkor arra is rákérdeztünk, hogy pontosan a gyermek hány hónapos korában valósult az meg.

Kíváncsiak voltunk arra is, hogy a gyermek aktív vagy passzív módon használja-e az eszközt. Az aktív használat azt jelentette, hogy a gyermek nemcsak fogyasztója a tartalomnak az adott médiaeszköz segítségével, hanem saját aktivitás is megvalósul a használatban (pl. egyedül, önállóan bekapcsolja, csatornát vált, beír valamit, játszik vele, keres stb.). A passzív használat ennek az ellentéte, vagyis azt jelenti, hogy a gyermek nem egyedül, önállóan használja az eszközt, csak a tartalmat fogadja be, saját aktivitás ennek során nem jelenik meg (pl. csak nézi a tévét vagy a videót a számítógépen, de ő maga nem választ tartalmat, nem vált csatornát stb.).

Az IKT-használat időtartamára is rákérdeztünk két technológia eszköz esetén.

Az egyik eszköz a televízió, mely során nemcsak a hétköznapi, hanem a hétvégi tévézés idejét is meg kellett becsülnie a szülőnek, valamint elkülönült a válaszlehetőségekben az is, hogy a gyermek ebben az időben ténylegesen a tévét nézi, vagy csak valami mást csinál bekapcsolt tévé mellett.

A számítógéphasználatnál szintén az aktív/passzív felhasználás mentén kérdeztünk rá az időtartamra, szintén elkülönítve a hétvégét és hétköznapot. Ezenkívül azt is megkérdeztük mindkét médiaeszköz kapcsán, hogy egyhuzamban meddig képes vele foglalkozni a gyermek, valamint jellemzően melyik napszakban használja őket.

Végül a használati szokások között megjelent a multitasking (pl. játék vagy mese közbe- ni médiahasználat), illetve médiamultitasking kérdése is (több médiaeszköz szimultán használata).

Az IKT-használat érzelmi tényezői alkották a következő kérdéscsoportot, ahol főként a problémás IKT-használatra utaló jelzéseket szerettünk volna feltárni, a következő területekre fókuszálva:

- Megjelennek-e a gyermeknél a feszültség jelei az IKT-eszköz hiányában (pl. „Feszült lesz, ha nincs bekapcsolva hosszabb ideig a televízió”)?

- Mindennapos szükségletként jelentkezik-e az IKT-használat a gyermeknél (pl. „Egy nap sem telik el úgy, hogy ne lenne bekapcsolva a televízió gyermekének")?

- Gondolataiban mennyire uralkodó az IKT-eszközökkel való foglalkozás (pl. „Ébredés után kéri, hogy kapcsolják be a televíziót")?

- Az eszközhöz való hozzáférés akadályoztatása esetén megjelennek-e a gyermeknél negatív érzelmi jelzések (pl. „Ha kérése ellenére nem kapcsolják be az eszközt (szomorú, kedvetlen, dühös lesz), sír és nehezen vigasztalódik")?

- Képes-e felülírni az IKT-eszközzel végzett tevékenység a gyermek más jellegü tevékenységét (pl. játék) (pl. „Abbahagyja az addig végzett (játék) tevékenységét, ha meghallja, hogy bekapcsolták a televíziót")?

- Mennyire követelőző a gyermek az IKT-eszközzel kapcsolatban („Dühösen követeli, hogy kapcsolják be a televíziót")?

Végül az utolsó kérdéscsoportba a gyermek IKT-használata feletti szülői kontroll kérdései kerültek; megjelenik-e a szülői felügyelet a gyermek tévé-, számítógép- és okostelefon használata közben, valamint kontrollálja-e a szülő a gyermek által megtekintett tartalmat és a gyermek médiahasználatának időtartamát. Mivel ezzel a kérdéssel kapcsolatban felmerül a szociális kívánatosság befolyásoló szerepe a szülők által adott válaszokban, így próbáltunk kicsit kevésbé direkt módon is rákérdezni arra, hogy megvalósul-e valóban a szülői kontroll a gyermek médiahasználata közben. Ennek érdekében olyan kérdéseket is feltettünk, hogy pl. mit csinál a szülö, 
amíg a gyermeke az IKT-eszközt használja, vagy milyen célból biztosítja a szülő az IKThasználatot gyermeke számára.

\section{Vizsgálati eredmények}

A kutatás során kapott eredmények elemzése során elsősorban arra voltunk kíváncsiak, hogy az általunk kapott adatok hogyan viszonyulnak a nemzetközi ajánlásokhoz, így a következőkben az eredményeket a fentiekben bemutatott Amerikai Gyermekgyógyászati Akadémia (AAP) által megfogalmazott ajánlások tükrében közöljük.

Az első ajánlás, hogy lehetőség szerint 1824 hónaposnál fiatalabb gyerekek ne hasz- náljanak digitális média eszközt (a videóchat kivételével).

Kérdőívünkben rákérdeztünk, hogy hány évesen használta először önállóan a gyermek a különböző IKT-eszközöket. A szülők a következő válaszlehetőségek közül választhattak; egyéves kora előtt, egy- és kétéves kora között, két- és hároméves kora között, hároméves kora után. Emellett rákérdeztünk arra is, hogy aki egyéves kora előtt kezdte el önállóan használni az adott IKT-eszközt, azt pontosan mikor (hány hónapos korában) tette. A következő táblázat az azokat a gyakoriságokat mutatja, ahol már a gyermek kétéves kora előtt megjelent az adott IKT-eszköz használata.

\begin{tabular}{|l|c|c|}
\hline \multicolumn{1}{|c|}{ IKT-eszköz } & Gyakoriság (fö) & Gyakoriság (\%) \\
\hline Televízió & 70 & 36,46 \\
\hline Okostelefon & 53 & 27,60 \\
\hline Tablet & 37 & 19,27 \\
\hline Rádió & 35 & 18,23 \\
\hline Hagyományos (nyomógombos) mobiltelefon & 25 & 13,02 \\
\hline Laptop & 20 & 10,42 \\
\hline Vezetékes telefon & 16 & 8,33 \\
\hline Asztali számítógép & 15 & 7,81 \\
\hline
\end{tabular}

1. táblázat: Kétéves kor előtti IKT-használat gyakorisága

Az első táblázatból látható, hogy a gyermekek 36,46\%-a nagyon korán, kétéves kora előtt elkezdi használni a televíziót, 27,60\% az okostelefont, 19,27\% pedig a tabletet.

Az AAP fontos ajánlása, hogy a szülő korlátozza a médiahasználat időtartamát; ez ne legyen több, mint napi egy óra az óvodás-, valamint csecsemő- és kisgyermekkorban lévő gyerekek esetében. Saját kérdőívünkben megkérdeztük, hogy mennyi időt tölt el a gyermek összesen a televízió, illetve a számítógép képernyője előtt egy átlagos hétköznap, illet- ve hétvégén. A televízióval kapcsolatban arra is kíváncsiak voltunk, hogy mennyi idő az, amikor kifejezetten a TV-képernyőre figyel a gyermek, és mennyi idő az, amikor a gyermek nem a televíziót nézi, hanem egyéb tevékenység (pl. játék, evés) közben be van kapcsolva a háttérben a TV-készülék. Az ezzel kapcsolatos eredményt a következő táblázat mutatja, melyben az ajánlásnak megfelelően azok a válaszok szerepelnek, ahol a gyermek több, mint egy órát tölt el tévénézéssel.

\begin{tabular}{|l|l|}
\hline \multicolumn{1}{|c|}{ Mikor nézi a tévét és hogyan? } & \multicolumn{1}{c|}{ Gyakoriság } \\
\hline Hétköznap - a tévére figyel & 66 fö $(34,38 \%)$ \\
\hline Hétköznap - mást csinál bekapcsolt tévé mellett & 85 fö (44,27\%) (több mint 5 órát: 8 fö) \\
\hline Hétvégén - a tévére figyel & 87 fó (45,31\%) (több, mint 5 órát: 1 fó) \\
\hline Hétvégén - mást csinál bekapcsolt tévé mellett & 92 fö (47,92\%) (több, mint 5 órát: 14 fó) \\
\hline
\end{tabular}

2. táblázat: Több mint egy órányi tévénézés gyakorisága hétköznap és hétvégén 
A második táblázat azt mutatja, hogy a gyerekek közel felénél jellemző, hogy napi egy óránál több időt töltenek el bekapcsolt televízió mellett. Ez az arány hétköznap kicsit kevesebb, mint hétvégén. Kifejezetten a tévét 34,38\% nézi egy óránál többet egy átlagos hétköznapon, 45,31\% pedig egy átlagos hétvégén. Emellett - bár kevés gyereknél - de megjelenik a több, mint 5 órát válasz is, föként azzal kapcsolatban, hogy a gyerek mást csinál a bekapcsolt készülék mellett.

Külön is rákérdeztünk arra, hogy a gyerek mennyi időt képes egyhuzamban tévézni. Egy óránál többet 16 gyerek képes egyhuzamban tévézni, ami a minta 8,33\%-a. Akik egy óránál kevesebb ideig képesek a tévét egyhuzamban nézni, ott az átlag tévézés 26,62 perc.

A számítógéphasználat időtartamával kapcsolatban azt különítettük el, hogy a gyermek aktívan vagy passzívan használja-e a számítógépet egy átlagos hétköznap, illetve hétvégén (az aktív és passzív használat jelentését a kérdőívet bemutató részben mutatjuk be részletesebben). A következő táblázat azokat az adatokat tartalmazza, ahol egy óránál többet használták a számítógépet a gyerekek.

\begin{tabular}{|l|l|}
\hline \multicolumn{1}{|c|}{ Mikor használja a számítógépet és hogyan? } & \multicolumn{1}{c|}{ Gyakoriság } \\
\hline $\begin{array}{l}\text { Hétköznap - aktív résztvevő (pl. keres, kattint, kiválaszt } \\
\text { stb.) }\end{array}$ & 13 fö (6,77\%) (több mint 5 órát: 1 fö) \\
\hline $\begin{array}{l}\text { Hétköznap - passzív megfigyelö (pl. csak nézi, hallgatja, } \\
\text { stb.) }\end{array}$ & 24 fö (12,5\%) \\
\hline $\begin{array}{l}\text { Hétvégén - aktív résztvevő (pl. keres, kattint, kiválaszt } \\
\text { stb.) }\end{array}$ & 21 fö (10,94\%) (több, mint 5 órát: 1 fö) \\
\hline $\begin{array}{l}\text { Hétvégén - passzív megfigyelö (pl. csak nézi, hallgatja, } \\
\text { stb.) }\end{array}$ & 34 fö (17,71\%) \\
\hline
\end{tabular}

3. táblázat: Több mint egy órányi számítógépezés gyakorisága hétköznap és hétvégén

A táblázatból látható, hogy a számítógépezés kisebb gyakorisággal jelenik meg ebben az életkorban napi egy óránál hosszabb időtartamban. A passzív használat jellemzőbb a gyerekekre, mint az aktív, valamint hétvégén inkább megjelenik a hosszabb időtartamú számítógépezés, mint hétköznap.

Szintén rákérdeztünk, hogy mennyi időt képes egyhuzamban számítógépezni a gyermek. A válaszadók gyermekinek 8,33\%-a (16 fö) képes egy óránál többet egyhuzamban számítógépezni. Akik azt válaszolták, hogy ez az időtartam kevesebb, mint egy óra, ott a számítógépezés átlagos időtartama 25,32 perc volt.

A Gyermekgyógyászati Társaság ajánlása szerint egy órával lefekvés előtt a gyermek már lehetőség szerint használja a technológiai eszközöket. Rákérdeztünk, hogy mely napszakban használják a gyerekek a televíziót és a számítógépet. Az ezzel kapcsolatos eredményeket a következő táblázat szemlélteti (a személyek ennél a kérdésnél több választ is megjelölhettek).

\begin{tabular}{|l|l|l|}
\hline \multicolumn{1}{|c|}{ Mikor használja az eszközt } & \multicolumn{1}{|c|}{ Gyakoriság - Televízió } & \multicolumn{1}{c|}{ Gyakoriság - Számítógép } \\
\hline Reggel 6-tól 10-ig & 75 fö & 40 fö \\
\hline Délelőtt 10-től 12-ig & 30 fó & 23 fó \\
\hline Kora délután 12-től 16-ig & 12 fö & 9 fó \\
\hline Késő délután 16-tól 19-ig & 113 fö & 89 fö \\
\hline Este 19-től 22-ig & 41 fó & 23 fó \\
\hline Éjszaka (22 óra után) & 0 fö & 0 fó \\
\hline
\end{tabular}

4. táblázat: Televízió- és számítógéphasználat ideje 
Éjszaka 22 óra után egyik gyermek sem használja sem a tévét, sem a számítógépet. Mindkét technológiai eszköz esetén kiemelkedő a késő délutáni használat (16 és 19 óra között), melyet a reggeli órák követnek (6 és 10 óra között). A televíziónál a harmadik leggyakoribb használati időpont az esti órákban (19 és 22 óra között) van, a számítógépezésnél szintén az esti órákban, valamint délelőtt (10 és 12 óra között).

Az AAP-ajánlás kitér a szülő szerepére is a gyermek médiahasználata alatt; fontos, hogy az ajánlott egy órában a szülő folyamatosan legyen a gyermek mellett, segítsen számára értelmezni a látottakat, hallottakat, vegyen részt a gyermek médiahasználatában. Annak érdekében, hogy felmérjük a szülői kontroll mértékét, több kérdést is feltettünk a szülők részére. Mivel ezzel kapcsolatban nagy esélye lehet annak, hogy a szülő a vélt társas elvárásoknak megfelelően válaszoljon, így több oldalról közelítettük meg a kérdést. Rákérdeztünk, hogy csak szülői felügyelettel használhatja-e otthon a televíziót, számítógépet, illetve okostelefont a gyermek. Mindhárom esetben az „igen” válasz aránya kiemelkedően magas volt a "nem”-hez képest. A számítógéphasználat esetében az igen-nem válaszok gyakorisága: igen: 111 fö $(57,81 \%)$ - nem: 14 fö (7,29\%); az okostelefon esetén: igen: 117 fö (60,94\%) - nem: 10 fö $(5,21 \%)$; a televíziónál: igen: 139 fó $(72,40 \%)$ - nem: 29 fö (15,10\%) (az értékek összege azért nem egyezik meg az elemszámmal, mert voltak szülők, akik azt jelölték meg, hogy nem használ a gyermekük egyáltalán ilyen eszközt).

Ezt követően rákérdeztünk arra, hogy miben nyilvánul meg a szülői korlátozás a televízióval, illetve számítógéphasználattal kapcsolatban. A legtöbb szülő mind a számítógép, mind a televízió esetében azt a választ jelölte be, hogy a gyermek által megtekintett tartalmat és az időtartamot is korlátozza, ameddig a gyermek használhatja az adott eszközt.

Ezen kérdések alapján összességében elmondható, hogy a szülők tudják, hogy szerepük van a gyermek médiahasználatával kapcsolatban, kontroll funkciót töltenek be. Ugyanakkor kérdéses, hogy ez a való életben is megnyilvánul-e. Ahhoz, hogy ezt kiderítsük, rákérdeztünk arra, hogy a szülő valóban a gyermekkel van-e, miközben ő a különböző médiaeszközöket használja, vagyis megkérdeztük, hogy mit csinál a szülő a leggyakrabban, miközben a gyermeke tévét néz vagy számítógépezik. A válaszokat a következő diagram szemlélteti a televíziónézés kapcsán (a szülők több választ is megjelölhettek, ebből adódik, hogy az összes válasz több, mint a vizsgálatban részt vevő személyek száma).

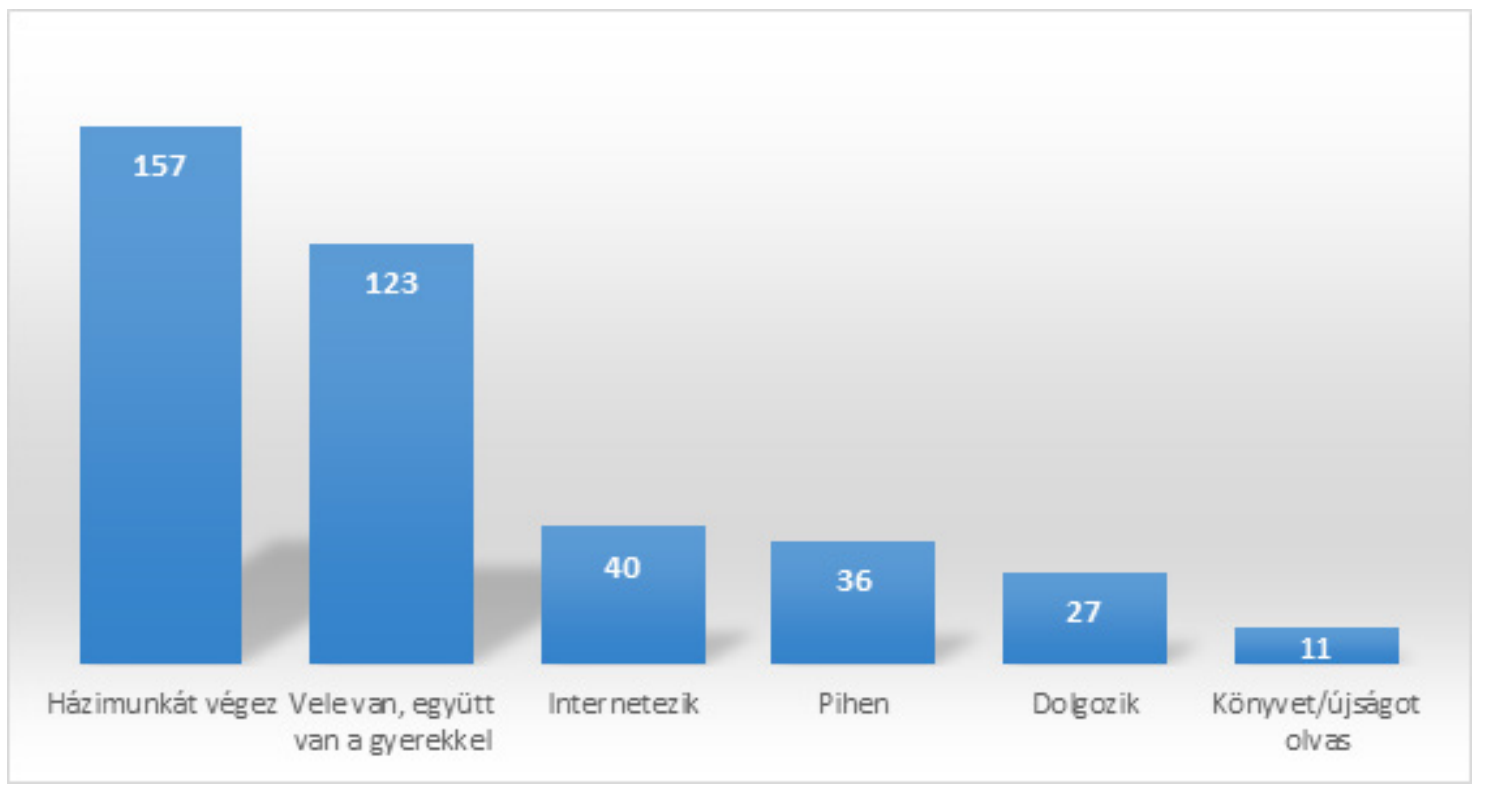

3. diagram: Mit csinál a szülő leggyakrabban, miközben gyermeke tévét néz 
A harmadik diagram azt mutatja, hogy összesen hány fő jelölte meg az adott válaszlehetőséget. A diagramról látható, hogy a leggyakoribb válasz az volt, hogy a szülő házimunkát végez, amíg a gyermek tévét néz (a 192 főből összesen 157-en jelölték meg ezt a választ, ami a teljes minta 81,77\%-a). A második leggyakoribb válasz az volt, hogy a szülő ebben az időben a gyermekkel van (123 szülö válaszolta ezt, ami a teljes minta 64,06\%-a).

A következő diagram ugyanezt szemlélteti a számítógépezéssel kapcsolatban.

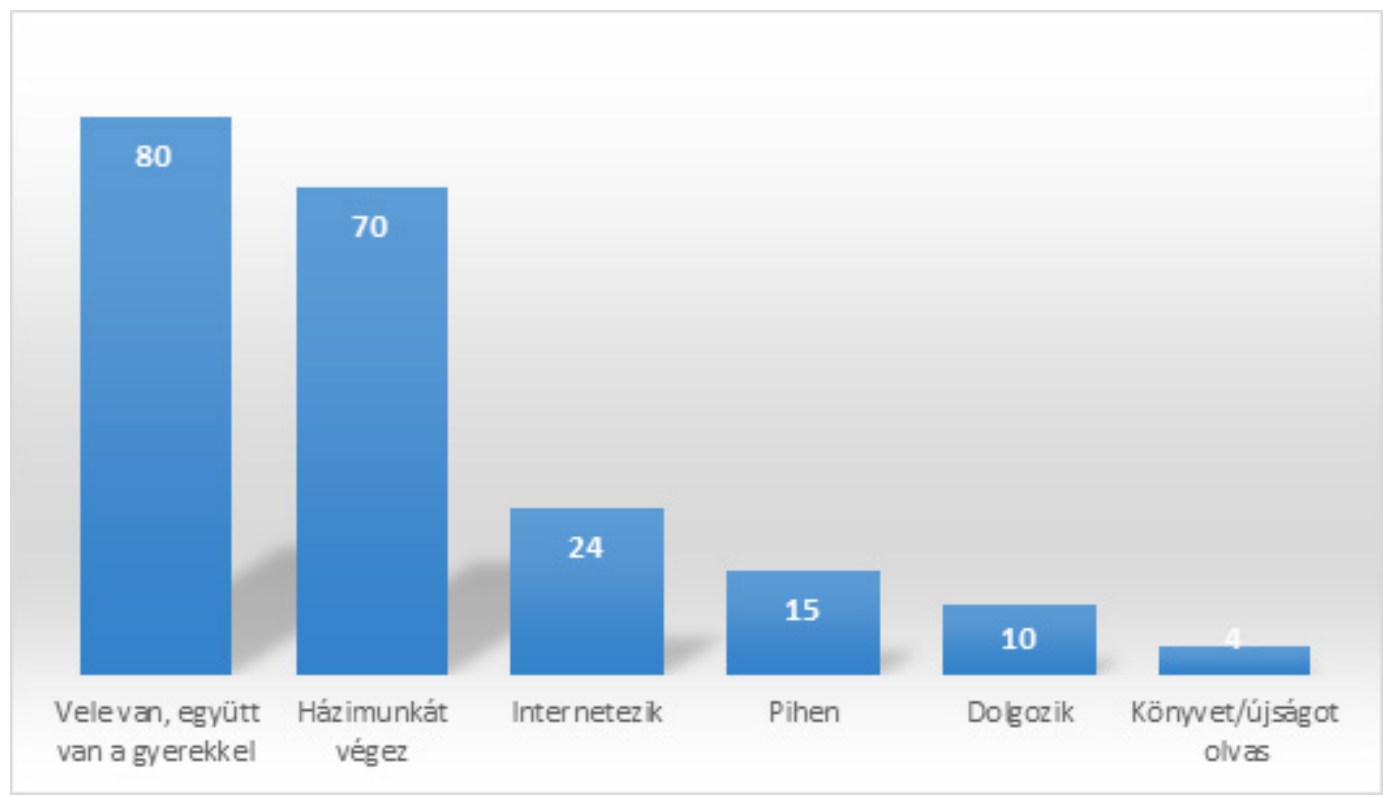

4. diagram: Mit csinál a szülő leggyakrabban, miközben gyermeke számítógépezik

A negyedik diagramról látható, hogy amíg a gyermek számítógépezik, addig a szülők 41,67\%-a (összesen 80 fö) együtt van a gyermekkel, 36,46\%-a (70 fö) házimunkát végez. Bár ezen technológiai eszköz esetén a legtöbb válasz valóban azt tükrözi, hogy a szülő a gyermekkel tölti ezt az időt, ugyanakkor nem sokkal marad el mögötte a „házimunkát végez" válaszlehetőség sem.

Végül rákérdeztünk arra is, hogy milyen céllal biztosítja a szülő a gyermek számára az IKTeszközök használatát. Az eredményt a következő diagram szemlélteti (szintén több választ is megjelölhettek a szülők a kérdőívben).

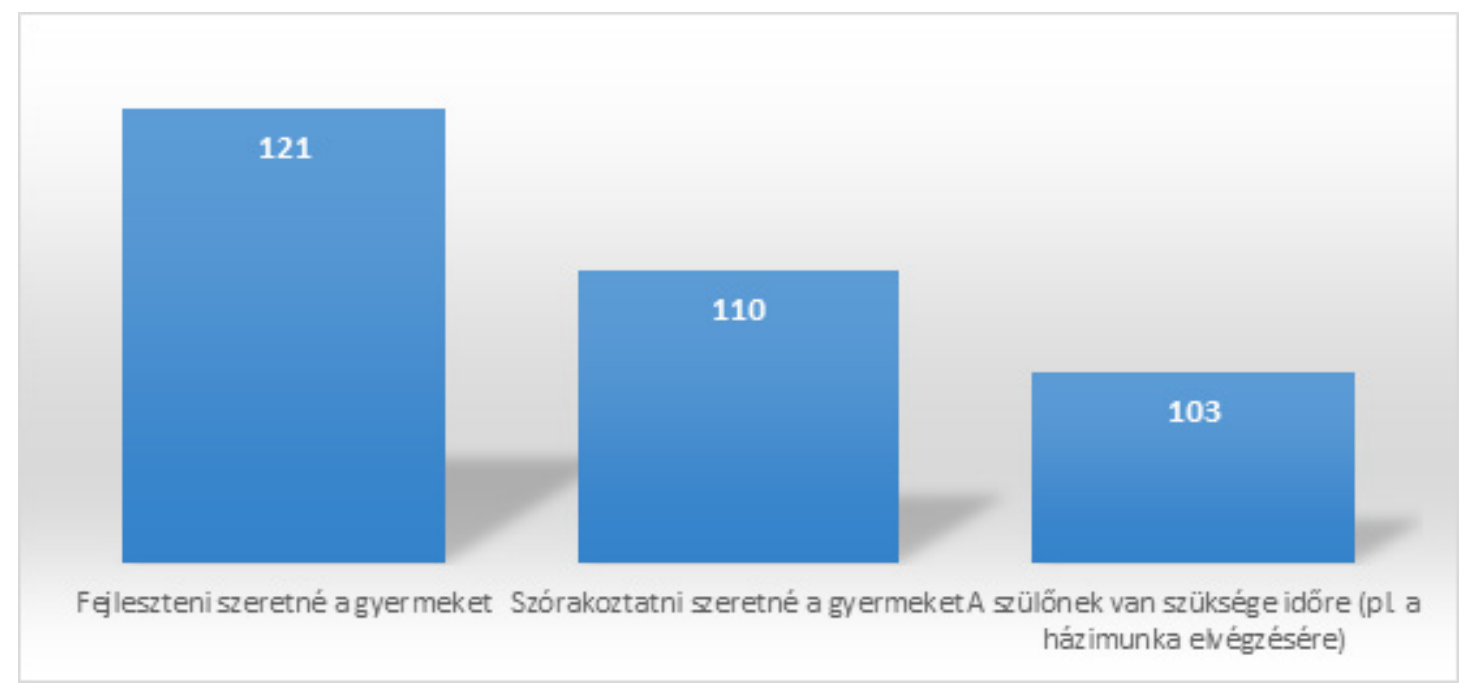

5. diagram: Milyen céllal biztosítja a szülő a gyermek számára az IKT-eszközök használatát 
Az ötödik diagramról látható, hogy a leggyakoribb válasz az volt, hogy a szülő fejleszteni szeretné gyermekét az eszközzel (ez a minta 63,02\%-ánál, 121 főnél jelent meg), ezt követi a gyermek szórakoztatásának igénye (a minta 57,29\%-ánál, 110 fónél jelent meg ez a válasz), végül pedig, hogy a szülőnek van szüksége időre, míg a gyermek lefoglalja magát (a minta 53,65\%-ánál jelent meg ez a válasz, összesen 103 fónél). Vagyis összességében látható, hogy mindhárom válaszlehetőség nagyjából hasonló arányban jelent meg a mintában.

Az AAP ajánlás kitér arra is, hogy a gyermek megnyugtatásának egyedüli eszközeként nem előnyös, ha a digitális médiát alkalmazza a szülő, mert az megnehezíti a gyermek számára a saját érzelemszabályozási stratégiák kialakítását. Ezzel kapcsolatban meg szerettük volna vizsgálni, hogy ebben a korai életkorban megjelennek-e bizonyos érzelmi válaszok az IKThasználattal kapcsolatban, amelyek problémás IKT-használatra is utalhatnak (pl. feszült lesz-e a gyermek, ha incs bekapcsolva az eszöz, eltelik-e úgy nap, hogy nem kapcsolják be az eszközt, mi történik, ha kérése ellenére nem kapcsolhatja be az eszközt, stb.). Létrehoztunk egy „problémás IKT-használat" nevezetű változót az ezekre a kérdésekre adott válaszokból, és megvizsgáltuk az összefüggését különböző tényezőkkel.

$\mathrm{Az}$ eredményeket a következő táblázat szemlélteti.

\begin{tabular}{|l|l|}
\hline & \multicolumn{1}{|c|}{ Problémás IKT-használat } \\
\hline Hétköznap a TV-re figyel & $\mathrm{r}=0,498, \mathrm{p}=0,0001$ \\
\hline Hétköznap mást csinál bekapcsolt TV mellett & $\mathrm{r}=0,145, \mathrm{p}=0,045$ \\
\hline Hétvégén a TV-re figyel & $\mathrm{r}=0,480, \mathrm{p}=0,0001$ \\
\hline Hétvégén mást csinál bekapcsolt TV mellett & $\mathrm{r}=0,126, \mathrm{p}=0,082$ \\
\hline Hétköznap aktív számítógéphasználat & $\mathrm{r}=0,535, \mathrm{p}=0,0001$ \\
\hline Hétköznap passzív számítógéphasználat & $\mathrm{r}=0,406, \mathrm{p}=0,0001$ \\
\hline Hétvége aktív számítógéphasználat & $\mathrm{r}=0,583, \mathrm{p}=0,0001$ \\
\hline Hétvége passzív számítógéphasználat & $\mathrm{r}=0,412, \mathrm{p}=0,0001$ \\
\hline
\end{tabular}

5. táblázat: A problémás IKT-használat változó összefüggései a televízió- és számítógéphasználattal

A problémás IKT-használat változó a korrelációs vizsgálat eredménye szerint közepesen erős pozitív kapcsolatban volt azzal, hogy a gyermek hétköznap és hétvégén mennyi időt tölt el azzal, hogy a tévére figyel, valamint gyenge pozitív kapcsolatot mutatott azzal, hogy a gyermek mennyi időt tölt el hétköznap úgy, hogy mást csinál bekapcsolt tévé mellett. Ez azt jelenti, hogy akár hétköznapról, akár hétvégéről is van szó, ha a gyermek összességében több időt tölt el azzal, hogy a tévét nézi, nagyobb valószínűséggel jelennek meg nála azok az érzelmi jelek, amelyek problémás IKT-használatra is utalhatnak.

A hétköznapi és hétvégi számítógépezésel töltött idő is pozitívan korrelált a problémás IKT-használat változóval, erősebb kapcsolatot láthatunk az aktív számítógéphasználat és problémás IKT-használat között, szemben a passzív használattal. Vagyis minél több időt tölt el a gyermek a számítógéphasználattal (akár hétköznap, akár hétvégén), annál inkább megjelennek nála azok az érzelmi tényezők, melyek a problémás IKT-használatra is utalhatnak. Ez a kapcsolat különösen erős az aktív számítógéphasználat esetén, vagyis akkor, amikor a gyermek nemcsak passzív fogyasztója, hanem aktív alakítója is a megtekintett tartalomnak.

Létrehoztunk egy új változót a televízió, illetve a számítógép előtt bármilyen formában eltöltött időtartamok alapján is, és megvizsgáltuk, hogy van-e összefüggés a problémás IKThasználat változóval. A Mann-Whitney próba eredményét a következő táblázat szemlélteti:

\begin{tabular}{|l|l|l|}
\hline & \multicolumn{1}{|c|}{ Átlagban TV elött töltött idő } & Átlagban számítógép elött töltött idő \\
\hline Problémás IKT-használat & $\mathrm{Z}=-3,38$ & $\begin{array}{l}\mathrm{Z}=-6,978 \\
\mathrm{p}=0,0001\end{array}$ \\
& $\mathrm{p}=0,001$ & \\
\hline
\end{tabular}

6. táblázat: Problémás IKT-használat és a TV és számítógép előtt töltött idő - a Mann-Whitney-próba eredményei 
Mindkét esetben szignifikáns a különbség az eszköz előtt töltött idő függvényében; minél több időt tölt el a gyermek átlagosan a tévé előtt, illetve a számítógép előtt, annál inkább megjelennek nála azok az érzelmi jelzések, melyek problémás IKT-használatra is utalhatnak.

A problémás IKT-használat változó a multitaskinggal is pozitív, közepes erősségü kapcsolatot mutatott $(\mathrm{r}=0,403, \mathrm{p}=0,0001)$, ami azt jelenti, hogy minél inkább hajlamos a gyermek arra, hogy az IKT-eszközzel végzett tevékenység mellett valami mást is csináljon (evés, játék). Illetve minél inkább jellemző rá a két vagy több médiaeszköz szimultán használata (média multitasking), annál inkább megjelennek azok az érzelmi jelzések, melyek a problémás IKT-használatra is utalhatnak.

Az AAP ajánlása szerint ebben az életkorban érdemes kerülni az olyan típusú médiahaszná- latot, amelynek a feldolgozására a gyermek éretlen idegrendszere még nem képes. Ilyen lehet a multitasking is, mely még egy érettebb idegrendszerrel rendelkező idősebb gyermek kognitív rendszerét is megterheli. Rákérdeztünk, hogy milyen gyakran fordul elő a gyermeknél, hogy játék vagy evés közben valamilyen IKTeszköz be van kapcsolva, illetve milyen gyakran jelenik meg a média multitasking jelensége (a válaszlehetőségek a következők voltak: soha; ritkábban, mint hetente (pl. havi egyszer-kétszer); hetente egyszer; hetente többször; naponta egyszer; naponta többször). A válaszok eloszlását a következő kördiagramok szemléltetik. A hatodik diagram azt mutatja, a gyerekek hány százalékánál fordul elő a média multitasking, vagyis két vagy több médiatartalom fogyasztása szimultán.

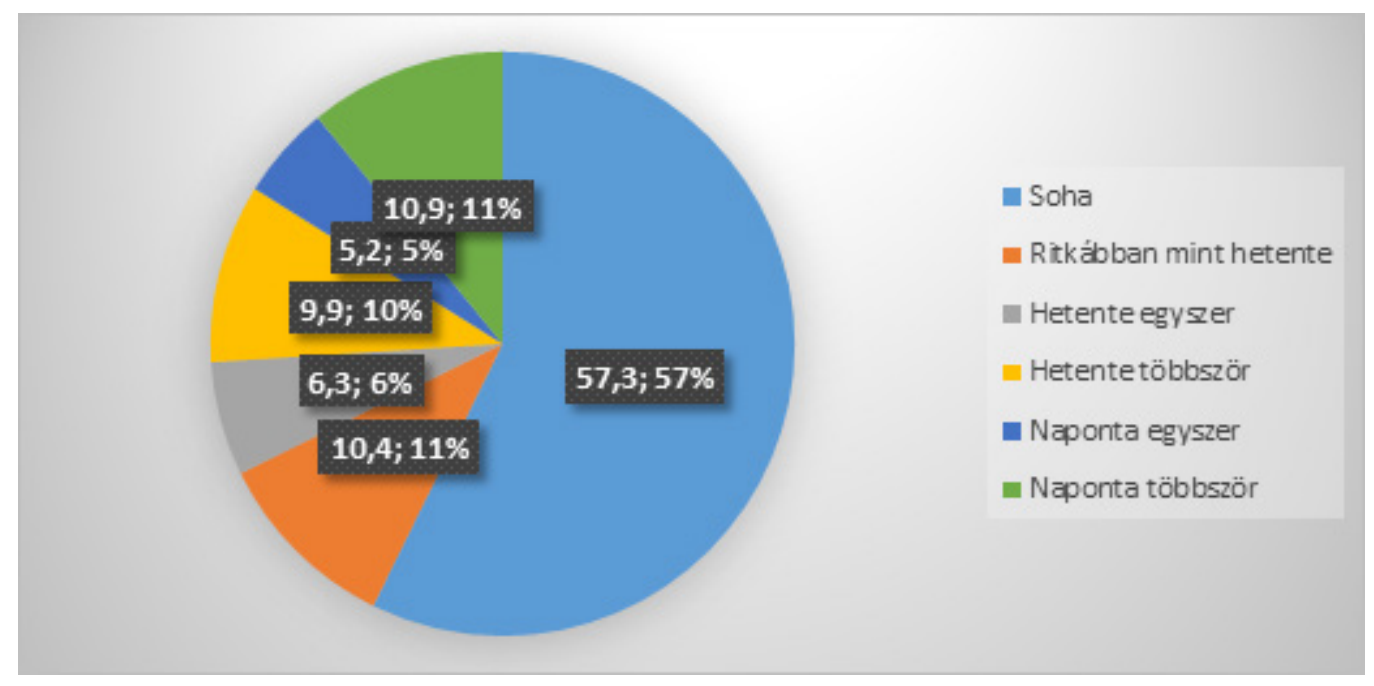

6. diagram: A média multitasking előfordulásának gyakorisága

A diagramról látható, hogy a média multitasking a gyerekek 57,3\%-ánál soha nem fordult még elő, viszont 10,9\%-nál naponta többször, 10,4\%-nál ritkábban, mint hetente megjeleik.

Az AAP-ajánlás kitér arra is, hogy legyenek olyan tevékenységek, amelyek közben nem megengedett az otthoni IKT-használat, mint például a mese, játék, vagy étkezés. A következő diagram azt mutatja, hogy menynyire jellemző, hogy játék közben szól a mese, zene a televízióban, képernyőn, amire néhanéha felpillant a gyermek.
A diagramról leolvasható, hogy a legnagyobb százalékban naponta többször is előfordul, hogy játék közben be van kapcsolva a tévé, amire a gyermek időnként felpillant (a gyerekek 27,6\%-ára jellemző), 18,8\%-nál ez hetente többször fordul elő. A következő diagram azt mutatja, hogy ugyanez jellemzö-e a gyermekekre evés közben. 


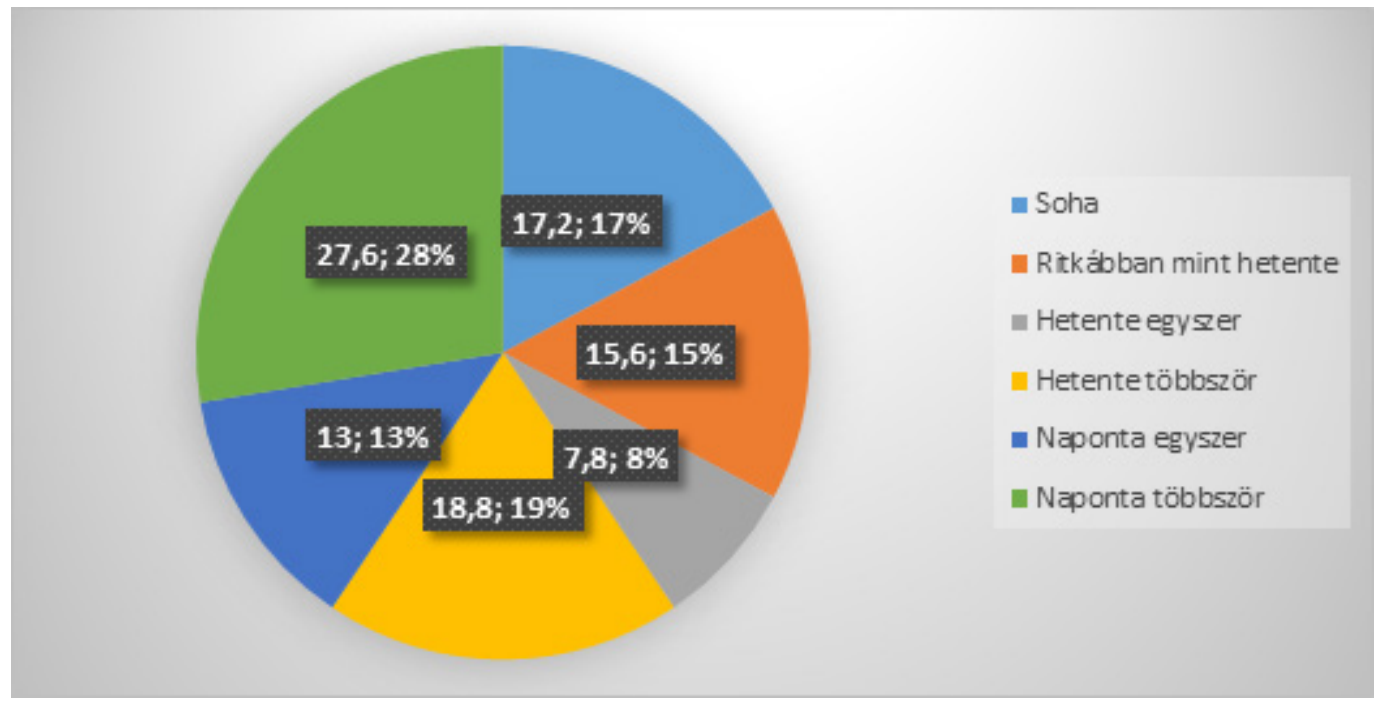

7. diagram: A játék közbeni IKT-használat előfordulásának gyakorisága

Evés közbeni tévénézés a minta 35,4\%ánál nem fordult még elő, viszont 19,3\%-nál előfordul ritkábban mint hetente, illetve szintén ennyi százaléknál naponta többször is.
Végül vizsgálatunkban rákérdeztünk arra is (csakúgy, mint a Nemzeti Média- és Hírközlési Hatóság 2018-as vizsgálatában), hogy a szülő szerint a tévénézésnek milyen hasz-

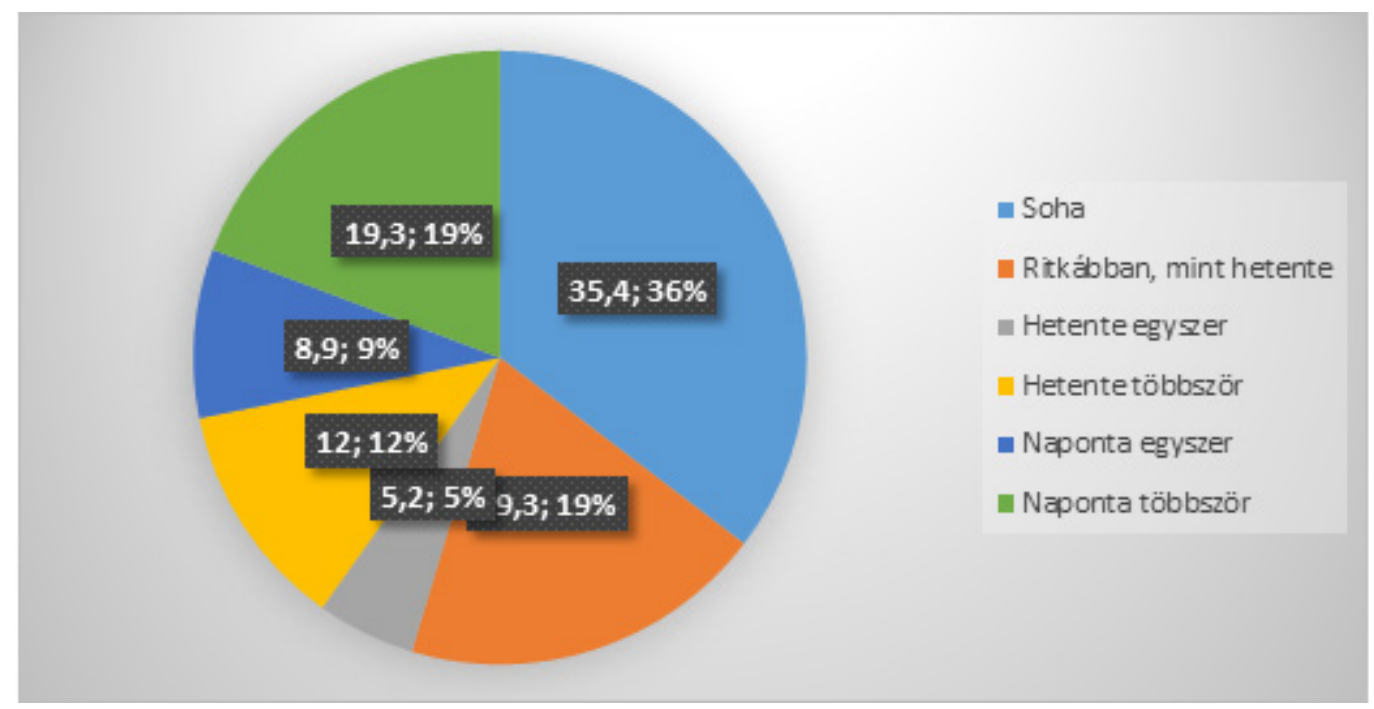

8. diagram: Az evés közbeni IKT-használat előfordulásának gyakorisága

nos funkciója lehet. A szülők szerint a tévénézés három leghasznosabb funkciója a következő volt; a televízió bővítheti a gyermek ismereteit (144 válasz szerint), fejlesztheti a gyermek szókincsét (121 válasz szerint), valamint segítheti, ösztönözheti az idegen nyelv tanulását (104 válasz szerint).

\section{Következtetések}

Összességében eredményeink azt mutatják, hogy a hat év alatti gyermekek IKT- használata nem minden esetben a nemzetközi ajánlásnak megfelelően alakul. A televízió, okostelefon és tablet használata emelkedett ki azok közül az eszközök közül, melyeket a gyermekek már kétéves kor előtt is önállóan használnak. A televízió már a korábbi kutatások szerint is kiemelkedő médiaeszköz a koragyermekkorban (Kostyrka-Allchorne et al., 2017b), az okostelefon és a tablet pedig valószínűleg könnyü kezelhetőségük (érintőképernyő) miatt kerül előtérbe ebben a korosztályban. 
Napi egy óránál többet tévézik hétvégén a gyerekek 45,31\%-a, ennél is magasabb azoknak az aránya, akik hétvégén mást csinálnak bekapcsolt tévé mellett (47,92\%). Ettől csak kevéssé maradnak el a hétköznapi arányok. A számítógéphasználat esetében már alacsonyabb arányokkal találkozunk; itt is a hétvégi, és főként a passzív módon történő számítógéphasználat emelkedett ki, bár a 20\%-ot sehol sem érte el. Összességében tehát elsősorban a televízió előtt eltöltött idő, amely a gyerekek nagy részénél meghaladja a Gyermekgyógyászati Társaság által ajánlott egy órát, bár a számítógéphasználat esetében is előfordul.

A gyerekek a legnagyobb arányban a késő délutáni órákban (16 és 19 óra között) használják a televíziót és a számítógépet is. Ez megkérdőjelezi, hogy valóban megvalósul-e, hogy egy órával lefekvés előtt nem használják már a gyermekek az IKT-eszközöket.

A szülői kontrollra vonatkozó kérdésekre adott válaszok arra utalhatnak, hogy a szülők pontosan tisztában vannak azzal, milyen szerepük van gyermekük médiahasználatával kapcsolatban; az okostelefont, számítógépet és televíziót a gyerekek legnagyobb része szülői felügyelettel használhatja csak, a szülők ellenőrzik a gyermekük által megtekintett tartalmat, valamint a televízió- és számítógéphasználat időtartamát is. Ugyanakkor felmerül a kérdés, hogy a szülők menynyire őszintén válaszoltak ezekre a kérdésekre, ha figyelembe vesszük arra a kérdésre adott válaszukat, hogy mit csinálnak, míg gyermekük tévét néz, illetve számítógépezik. A szülők több, mint 80\%-a házimunkát végez, míg a gyermeke tévézik, ez az arány 36,46\% a gyermek számítógépezése közben. Tehát felmerül a kérdés, hogy a szülő által alkalmazott kontroll mennyire valósul meg valójában. Az AAP ajánlás szerint a koragyermekkorban médiahasználattal eltöltött maximum egy órát szoros szülői ellenőrzés alatt kellene megvalósítani, azonban ez nem biztos, hogy teljesül, ha a szülő közben mással van elfoglalva.

A problémás IKT-használatra utaló érzelmi válaszok pozitív összefüggést mutattak a tévé- nézés, valamint a számítógéphasználat idejével - föként az aktív jellegű számítógéphasználat esetében (bár a passzív használatnál is szignifikáns volt a kapcsolat). Vagyis a tévénézés és a számítógéphasználat megnövekedett időtartama együttjár azoknak az érzelmi jelzéseknek a megjelenésével, melyek arra utalnak, hogy a gyermek distresszt él át, ha az IKT-eszköz használata nem elérhető, az eszköz használata képes más tevékenységét felülírni. A problémás IKT-használatra utaló jelzések emellett a multitasking gyakoriságával is pozitív együttjárást mutattak.

A multitasking, többszörös feladatvégzés megterhelő lehet egy idősebb gyermek, serdülő, vagy felnőtt kognitív müködése számára is. Koragyermekkorban az éretlen idegrendszer fokozottabban ki van téve a multitasking negatív hatásának. Ennek ellenére a média multitasking a gyerekek 10,9\%-ánál, a játék közbeni tévézés a gyerekek 27,6\%-ánál, míg az evés közbeni tévézés a gyerekek 19,3\%ánál naponta többször is előfordul.

Két kérdésünk eredményét összehasonlíthatjuk a Nemzeti Média- és Hírközlési Hatóság 2018-as vizsgálatában talált eredményekkel. Az egyik, hogy milyen céllal biztosítja a szülő a gyermek számára az IKT-eszközök használatát. Mindkét vizsgálatban közel azonos arányban jelent meg a három válaszlehetőség (fejleszteni szeretné gyermekét, szórakoztatni szeretné gyermekét, a szülőnek van szüksége időre). Másik kérdésünk arra vonatkozott, hogy a szülő szerint milyen hasznos funkciója lehet a tévénézésnek. A saját vizsgálatunkban megjelenő három leggyakoribb válasz szintén egybecsengett a Nemzeti Média- és Hírközlési Hatóság 2018-as vizsgálatában megjelenő eredményekkel; a televízió bővítheti a gyermek ismereteit, fejlesztheti a gyermek szókincsét, valamint segítheti, ösztönözheti az idegen nyelv tanulását.

Összességében tehát eredményeinkből az látható, hogy az általunk vizsgált kisgyermekkorban lévő gyermekek médiahasználata nem igazán felel meg annak, amit az Amerikai Gyermekgyógyászati Társaság az ajánlásában ezen korosztály részére megfogalmaz. A szülők valószínűleg nincsenek tö- 
Infokommunikációs technológia használata kora gyermekkorban

kéletesen tisztában ezekkel az ajánlásokkal, így a legfontosabb feladat az lenne, hogy számukra segítséget nyújtsunk gyermekük IKThasználatával kapcsolatban. Ennek részeként nemcsak a nemzetközi ajánlások megismertetése jelenhetne meg, hanem a szülők célzott támogatása is abban, hogy hogyan tudnak segíteni gyermeküknek egészen koragyermekkortól a megfelelő, adaptív IKT-használat megalapozásában.

Tervezzük a kutatás nagyobb mintára történő kiterjesztését. A nagymintás vizsgálatok eredményeinek publikálásával kutatócsoportunk a koragyermekkori IKT-használatra vonatkozó ajánlások kidolgozását tervezi, amely illeszkedik a hazai viszonyokhoz, és a szülőkön túl a kisgyermeknevelésben érintett valamennyi partner számára irányelvet jelenthet a gyermekek fejlődését szolgáló korai IKThasználat optimális kezelésére.

\section{Felhasznált irodalom}

AAP Council on Communications and Media. (2016): Media and Young Minds. Pediatrics, 138. 5 . sz. https://doi.org/10.1542/peds.2016-2591

Casey, B. J., Tottenham, N., Liston, C. \& Durston, S. (2005): Imaging the developing brain : what have we learned about cognitive development? Trends in Cognitive Sciences, 9. 3. sz., 104-110.

https://doi.org/10.1016/j.tics.2005.01.011

Demetrovics Zsolt (2013): Viselkedési addikciók: spektrumszemlélet és kutatások. Akadémiai doktori értekezés.

Dorner László, Hatvani Andrea, Taskó Tünde, Soltész Péter, Estefánné Varga Magdolna és Dávid Mária (2016): IKT-használat 10-18 éveseknél. Egy IKT-eszközhasználati kérdőív bemutatása. Magyar Pszichológiai Szemle, 71. 1/2. sz., 25-56. https://doi.org/10.1556/0016.2016.71.1.2

Fekete Sándor és Vörös Viktor (2016): Dependenciák pszichobiológiája. In: Emberi életfolyamatok idegi szabályozása - a neurontól a viselkedésig. Pécsi Tudományegyetem: Dialóg Campus Kiadó-Nordex Kft. Retrieved from https://www.tankonyvtar.hu/hu/tartalom/ tamop412A/2011-0094_neurologia_hu/ ch05s11.html

Feldmann, Á., \& Nagy, A. (2016). Agyi plaszticitás gyermek- és felnőttkorban. In: Emberi életfolyamatok idegi szabályozása - a neurontól a viselkedésig. Pécsi Tudományegyetem - Dialóg Campus - Kiadó-Nordex Kft. URL: https://www.tankonyvtar.hu/hu/ tartalom/tamop412A/2011-0094_neurologia_ $\mathrm{hu} / \mathrm{ch} 05 \mathrm{~s} 17 . \mathrm{html}$

Kostyrka-Allchorne, K., Cooper, N. R. \& Simpson, A. (2017a): The relationship between television exposure and children's cognition and behaviour: A systematic review. Developmental Review, 44., 19-58.

https://doi.org/10.1016/j.dr.2016.12.002

Kostyrka-Allchorne, K., Cooper, N. R. \& Simpson, A. (2017b): Touchscreen generation: children current media use, parental supervision methods and attitudes towards contemporary media. Acta Paediatrica, 106., 654-662.

https://doi.org/10.1111/apa.13707

Nemzeti Média- és Hírközlési Hatóság. (2018): A három éven aluli gyermekek médiahasználati szokásai.

Shore, R. (1997): Rethinking the Brain: New Insights into Early Development. Families and Work Institute, New York.

Takeuchi, H., Taki, Y., Asano, K., Asano, M., Sassa, Y., Yokota, S., Kotozaki, Y., Nouchi, R \& Kawashima, R. (2018): Impact of frequency of internet use on development of brain structures and verbal intelligence : Longitudinal analyses. Human Brain Mapping, 39. 11. sz., 4471-4479. https://doi.org/10.1002/hbm.24286

Wilmer, H. H., Sherman, L. E. \& Chein, J. M. (2017): Smartphones and Cognition: A Review of Research Exploring the Links between Mobile Technology Habits and Cognitive Functioning. Frontiers in Psychology, 8. 605. sz., 1-16.

https://doi.org/10.3389/fpsyg.2017.00605 


\section{Usage of info-communication technology in early childhood}

In this study we look through the national and the international results of studies on usage of information and communication technologies ( $T V$, internet) in early childhood, and we show the results of the empirical studies made by the Eszerházy Károly University. The goal of our study was to explore the habits of ICT usage of children under 6 years of age by questioning their parents. The ICT use questionnaire developed by us, and the main results of the questionnaire survey will be presented. Our results show that ICT usage of children under 6 years of age doesn't always fit the international recommendations. By the outcome the most important job of the professionals is the specialized support of parents in helping their children from the early childhood to ground the proper, adaptive ICT usage.

Keywords: early childhood, ICT usage, multitasking, parenting control 